\title{
Estimating Cloud and Rain Parameters from Doppler Radar Data
}

\author{
O. Bezvesilniy, G. Peters ${ }^{1}$, and D. Vavriv \\ Institute of Radio Astronomy, \\ Chervonopraporna St. 4, \\ 61002, Kharkov, Ukraine, \\ Email:obezv@rian.kharkov.ua \\ Email:vavriv@rian.kharkov.ua \\ ${ }^{1}$ Meteorological Institute, University Hamburg, \\ Bundesstrasse 55, \\ D 20146 Hamburg, Germany, \\ E-mail:peters@miraculix.dkrz.de
}

Received December 3, 2002

Real-time mapping of the parameters of precipitating water clouds and rain making use of a vertically-directed Doppler radar is an important problem. In this paper, an algorithm based on an independent estimation of the droplet effective diameter and concentration is suggested. This approach differs from the Marshall-Palmer retrieval procedure that is based on a single estimated parameter, the radar reflectivity factor.

It is shown that the Marshall-Palmer approach can provide good estimates of the averaged parameters, however is not suitable for producing the high resolution time-height maps of the parameters. The two-parameter retrieval algorithm under discussion was tested using the data obtained with the $36 \mathrm{GHz}$ polarimetric Doppler cloud radar MIRA-36. The results of the measurements and their processing are presented. The algorithm suggested has appeared to be applicable for real-time measurements with the vertically-directed Doppler radars.

\section{Introduction}

The paper is devoted to real-time retrieval of the water cloud and rain parameters with a vertically-directed Doppler radar. This problem has been considered by many researchers [1-5] because of its importance for practical applications.

One of the basic characteristics of water clouds and rain is the drop size distribution (DSD). The typical, often used form of the DSD is the Gamma-distribution [1-2],

$$
N(D)=\frac{N_{0}}{D_{0}} \frac{1}{\Gamma(\mu+1)}\left(\frac{D}{D_{0}}\right)^{\mu} e^{-\frac{D}{D_{0}}} .
$$

Here $\Gamma(\mu)$ is the Gamma-function. This form of the DSD depends on three parameters, namely the droplet concentration, $N_{0}\left[\mathrm{~m}^{-3}\right]$; the droplet effective diameter, $D_{0}[\mathrm{~mm}]$; and the parameter $\mu$, which is assumed to be known. Two particular cases are often considered [1-2], specifically $\mu=0$, which is used for rain drops, and $\mu=2$, which is for cloud droplets.

The drop size distribution determines several integral parameters. For example, the liquid water content, $L W C\left[\mathrm{~g} / \mathrm{m}^{3}\right]$, is proportional to the third moment of the distribution,

$L W C=10^{-3} \frac{\pi}{6} \int_{0}^{\infty} D^{3} N(D) \mathrm{d} D$.

Substituting the DSD in the form (1), one can obtain the following expressions:

$$
L W C=10^{-3} \frac{\pi}{6} \frac{\Gamma(\mu+1+3)}{\Gamma(\mu+1)} N_{0} D_{0}^{3},
$$


or

$$
L W C=10^{-3} \pi N_{0} D_{0}^{3}, \quad(\text { for } \mu=0) .
$$

The radar reflectivity factor, $Z\left[\mathrm{~mm}^{6} \cdot \mathrm{m}^{-3}\right]$, which describes the backscattered power is proportional to the sixth moment of the distribution,

$Z=\int_{0}^{\infty} D^{6} N(D) \mathrm{d} D$

so that

$Z=\frac{\Gamma(\mu+1+6)}{\Gamma(\mu+1)} N_{0} D_{0}^{6}$,

or

$Z=720 \cdot N_{0} D_{0}^{6}, \quad($ for $\mu=0)$.

Similarly to the effective diameter and the droplet concentration, the droplet velocity, $V[\mathrm{~m} / \mathrm{s}]$, is an important microphysical parameter. It is a sum of the terminal fall velocity of droplet, $V_{g}(D)>0$, the mean air flow velocity, $V_{a}$, and the turbulent air flow velocity, $V_{t}[1-4]$,

$V=V_{a}-V_{g}(D)+V_{t}$.

The turbulent velocity of droplets is a random quantity characterized by a zero-mean Gaussian distribution [1-3] with the variance $\sigma_{t}$. The turbulent velocity is supposed to be independent of the droplet diameter. The terminal fall velocity depends on the droplet diameter. We have used the following approximation [2]:

$V_{g}(D)=3.778 \cdot D^{0.67}=V_{g}\left(D_{0}\right)\left(D / D_{0}\right)^{0.67}$.

The parameter as important as the rainfall rate, $R[\mathrm{~mm} / \mathrm{h}]$, depends both on the drop size distribution and the droplet vertical velocity,

$$
R=3.6 \cdot 10^{-3} \frac{\pi}{6} \int_{0}^{\infty} D^{3}\left(V_{g}(D)-V_{a}\right) N(D) \mathrm{d} D .
$$

$$
\begin{aligned}
& R=3.6 \cdot 10^{-3} \frac{\pi}{6} N_{0} D_{0}^{3} \times \\
& \times\left(\frac{\Gamma(\mu+1+3+0.67)}{\Gamma(\mu+1)} V_{g}\left(D_{0}\right)-\frac{\Gamma(\mu+1+3)}{\Gamma(\mu+1)} V_{a}\right) \\
& R=3.6 \cdot 10^{-3} \pi N_{0} D_{0}^{3}\left(2.46 V_{g}\left(D_{0}\right)-V_{a}\right)
\end{aligned}
$$

(for $\mu=0$ ).

Modern vertically-directed Doppler radars provide the real-time images of the radar reflectivity factor, the mean Doppler velocity, and the Doppler spectrum width. These values can be used to retrieve the cloud and rain parameters. In our research we used the Doppler cloud radar MIRA-36 [6] operating at the frequency of $36 \mathrm{GHz}$. The radar characteristics are listed in a Table.

Table. Characteristics of the radar MIRA-36

\begin{tabular}{l|c}
\hline Frequency & $36 \mathrm{GHz}$ \\
Peak power & $30 \mathrm{~kW}$ \\
Pulse width & $100 \div 400 \mathrm{~ns}$ \\
Pulse repetition frequency & $2.5,5.0$, or $7.5 \mathrm{kHz}$ \\
Antenna beam width & $0.6^{\circ}$ \\
Range resolution & $15 \div 60 \mathrm{~m}$ \\
Time resolution & $0.1 \mathrm{~s}$ \\
$\begin{array}{l}\text { Doppler analysis } \\
\text { FFT length }\end{array}$ & $\mathrm{FFT}$ \\
Maximum unambiguous & $128,256,512$ \\
& $\pm 15 \mathrm{~m} / \mathrm{s}$ \\
Doppler spectrum resolution & $5 \mathrm{~cm} / \mathrm{s}$ \\
Polarization & \\
Transmitter & Single polarization \\
Receiver & Dual polarization \\
Remote control and & TCP/IP (the Internet) \\
\hline
\end{tabular}


The aim of this paper is to propose an algorithm for real-time retrieval of the high-resolution images of the effective droplet diameter, the droplet concentration, the liquid water content, the vertical air flow velocity, and the rainfall rate. These additional images will improve the radar capacity for real-time observations of precipitation events and will provide important information on the cloud and rain structure.

The paper is organized as follows. The introduction is followed by a brief review of the classical retrieval approach based on the MarshallPalmer expressions. Then a two-parameter retrieval algorithm is considered. After that, results of the algorithm application are discussed. The paper ends with a brief conclusion.

\section{Marshall-Palmer Approach}

Several retrieval algorithms have already been proposed. The classical approach is based on the Marshall-Palmer retrieval expressions [1-4]. According to this approach, an empirical relation is assumed between the droplet effective diameter and the droplet concentration,

$N_{0} / D_{0}=8000 \mathrm{~m}^{-3} / \mathrm{mm}$.

Moreover, the vertical air flow velocity is supposed to be small as compared to the terminal fall velocity, and an empirical relation for the rainfall rate is introduced,

$$
1 / D_{0}=4.1 \cdot R^{-0.21}
$$

Thus, the Marshall-Palmer approach allows retrieving the cloud and rain parameters from a single measured value, the radar reflectivity factor,

$$
Z=200 \cdot R^{1.6}, \quad L W C=0.072 \cdot R^{0.88} .
$$

The scheme of the approach is given in Fig. 1. Proceeding from the reflectivity factor, the rainfall rate is estimated, and then the effective diameter, the droplet concentration and the liquid water content are retrieved.

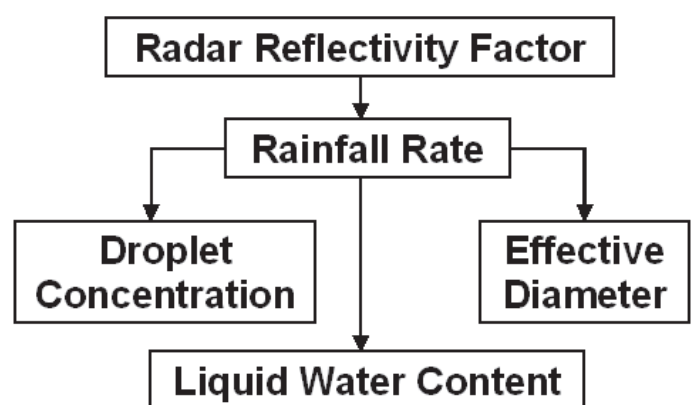

Fig. 1. Marshall-Palmer approach

However, it has been found out that the empirical relation between the effective diameter and the droplet concentration varies considerably. A number of similar empirical expressions with other numerical coefficients have been proposed. The diversity of this relations, on the one hand, comes from the variety of the precipitation conditions, and, on the other hand, is a result of inhomogeneity of the clouds and rain with time and height. Therefore, the Marshall-Palmer expressions are applicable for estimating the averaged cloud and rain parameters and not suitable for retrieving the high-resolution images of the parameters.

\section{Two-Parameter Retrieval Approach}

We have not postulated the relation between the droplet effective diameter and concentration. Instead, we have used the retrieval algorithm based on an independent estimation of these two parameters. As will be shown below, the droplet effective diameter can be estimated from the Doppler spectrum width. The droplet concentration can be then retrieved from the reflectivity factor (3).

In case of incoherent Rayleigh scattering, the radar backscattered signal (IQ-signal) is a zeromean stationary random process with a wellknown correlation function [1, 2, 5, 7],

$$
\begin{aligned}
& R(\tau)=P_{s} \exp \left[-2 i k V_{a} \tau\right] \times \\
& \times \frac{\left\langle\sigma(D) \exp \left[2 i k V_{g}(D) \tau\right]\right\rangle}{\langle\sigma(D)\rangle}\left\langle\exp \left[-2 i k V_{t} \tau\right]\right\rangle
\end{aligned}
$$


Here $P_{s}$ is the signal power, and $\sigma(D) \sim D^{6}$ is the Rayleigh backscattering cross section. Using (6), one can obtain the formula for the Doppler spectrum moments,

$$
\left\langle V^{n}\right\rangle=\frac{\left\langle\sigma(D)\left[V_{a}-V_{g}(D)+V_{t}\right]^{n}\right\rangle}{\langle\sigma(D)\rangle} .
$$

In particular, the mean Doppler velocity measured by radar is a sum of the mean vertical air flow velocity, $V_{a}$, and the mean terminal fall velocity of droplets, $V_{g}$,

$\langle V\rangle=V_{a}-V_{g}$,

$V_{g}=\frac{\left\langle\sigma(D) V_{g}(D)\right\rangle}{\langle\sigma(D)\rangle}=V_{g}\left(D_{0}\right) \frac{\Gamma(\mu+6+0.67+1)}{\Gamma(\mu+6+1)}$.

The Doppler spectrum width, $\sigma$, is a sum of the turbulent spread, $\sigma_{t}$, and the spread due to dispersion of the terminal fall velocity of droplets, $\sigma_{g}$,

$$
\sigma^{2}=\sigma_{g}^{2}+\sigma_{t}^{2}
$$

$$
\begin{aligned}
& \sigma_{g}^{2}=\frac{\left\langle\sigma(D) V_{g}^{2}(D)\right\rangle}{\langle\sigma(D)\rangle}-V_{g}^{2}= \\
& =V_{g}^{2}\left(D_{0}\right) \frac{\Gamma(\mu+6+2 \cdot 0.67+1)}{\Gamma(\mu+6+1)}-V_{g}^{2},
\end{aligned}
$$

For the case of $\mu=0$,

$$
\begin{aligned}
& V_{g}=3.6 \cdot V_{g}\left(D_{0}\right), \\
& \sigma_{g}=0.92 \cdot V_{g}\left(D_{0}\right) .
\end{aligned}
$$

Thus, the main idea of the two-parameter approach consists in the following. The spectrum spread due to dispersion of the terminal fall velo- city of droplets depends on the droplet effective diameter. Therefore, if the turbulent spread is small, the effective diameter can be estimated based on the Doppler spectrum width (9). The droplet concentration can be then retrieved from the reflectivity factor (3). Thus, within the framework of this algorithm, the effective diameter and the droplet concentration are estimated independently, in contrast to the Marshall-Palmer approach. Calculating the mean terminal fall velocity of the droplets (8) and using the measured value of the mean Doppler velocity, the vertical air flow velocity can be extracted (7). Finally, the liquid water content (2) and the rainfall rate (4) can be retrieved.

The scheme of the retrieval algorithm is shown in Fig. 2.

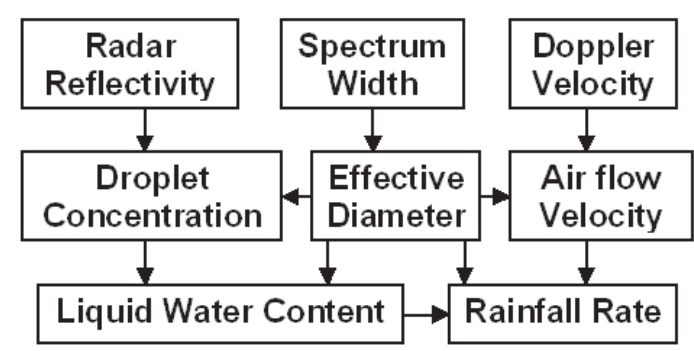

Fig. 2. Two-parameter approach

In case of the fine-droplet clouds, the turbulent spread is comparable to the spread due to dispersion of the terminal fall velocity of droplets. The typical values of the spectrum width observed in these clouds are less than about $0.2 \mathrm{~m} / \mathrm{s}$. This value corresponds to the effective diameter of about $15 \mu \mathrm{m}$. This diameter has been considered as the minimum effective diameter that can be estimated within the framework of the approach discussed. Thus, our two-parameter approach is suitable for retrieving the parameters of precipitating water clouds and weak or moderate rain.

\section{Results and Discussion}

The retrieval approach suggested has appeared to be a convenient tool for the real-time estimation of the cloud and rain parameters. This has 
been demonstrated with the K-band cloud Doppler radar MIRA-36. The images of the retrieved droplet effective diameter and the droplet concentration for the case of weak rain and for the region below the melting layer are shown in Figs. 3 and 4.

To examine the dependences between different cloud and rain parameters, the two-dimensional histograms have been built in the twoparameter planes. Let us consider the histogram of the measured values of the mean Doppler velocity and the Doppler spectrum width in the plane "velocity - spectrum width" shown in Fig. 5. The retrieval approach discussed is based on the assumption that the Doppler spectrum width is mainly determined by dispersion of the terminal fall velocity of droplets. Under this assumption, if there are no strong vertical air flows, the measured mean Doppler velocity should be on average linearly proportional to the Doppler spectrum width, (8), (9). This theoretical dependence is shown in Fig. 5 as a grey line. One can see that the theoretical relation is on average consistent with the observed distribution. Thus, we can conclude that in case of precipitating clouds and rain the spectrum width is principally determined by the dispersion of the terminal fall velocity of droplets.

\section{Droplet Effective Diameter, mm}

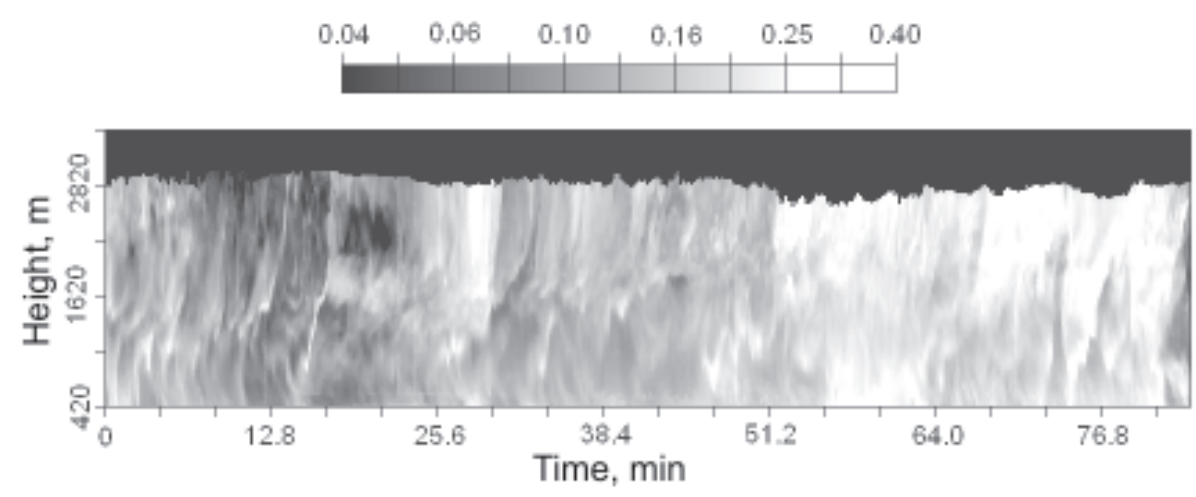

Fig. 3. Image of the retrieved droplet effective diameter

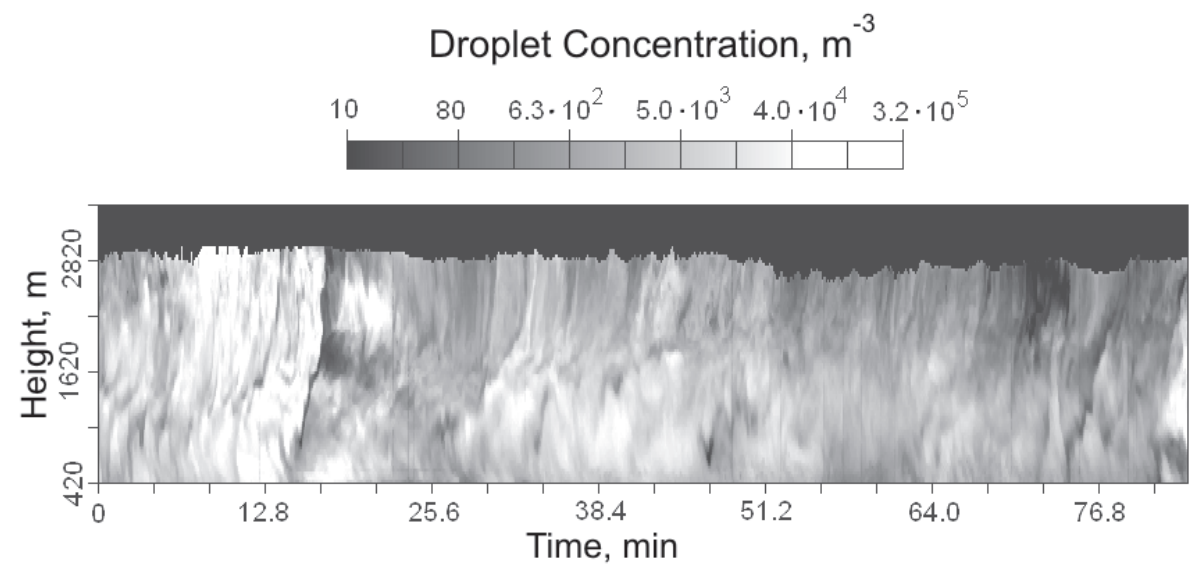

Fig. 4. Image of the retrieved droplet concentration 


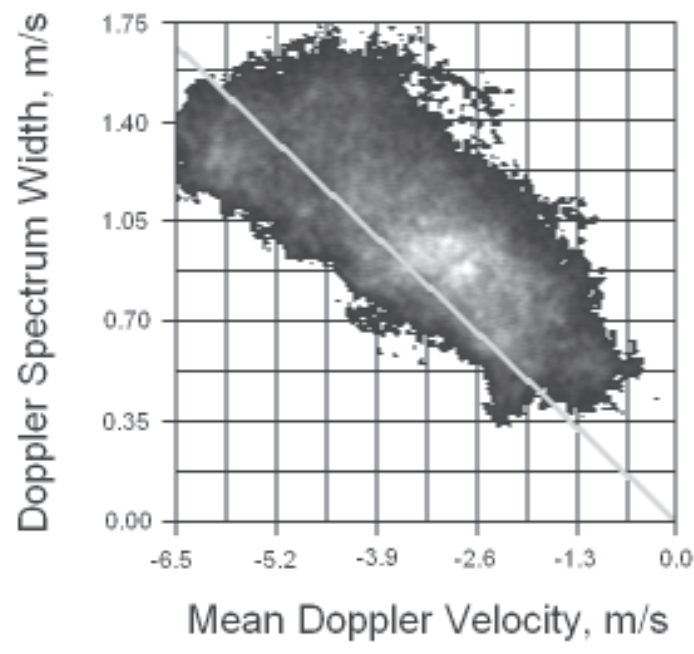

Fig. 5. The histogram of the measured values of the mean Doppler velocity and the Doppler spectrum width

In Fig. 6, the histogram in the plane of the retrieved parameters "effective diameter - concentration" is shown. According to this figure, on average the concentration decreases with the diameter. This is in contrast to the Marshall-Palmer relation (5) which is plotted in this figure as a light grey line and shows the reverse dependence. However, this line crosses the maximum of the distribution, implying that the Marshall-Palmer retrieval expressions allow to estimate the averaged values of the parameters.

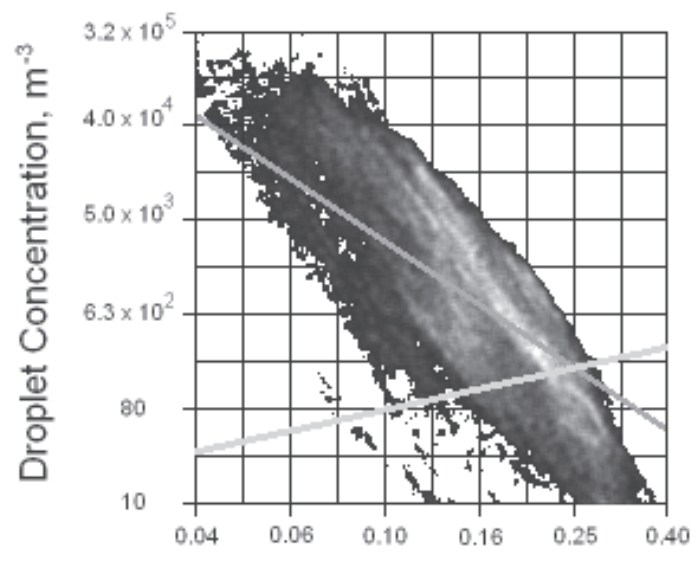

Droplet Effective Diameter, $\mathrm{mm}$

Fig. 6. The histogram on the plane of the retrieved effective diameter and the droplet concentration
The observed distribution can be interpreted as follows. If the effective diameter and the concentration are varying while the liquid water content retains constant, then the concentration is a reciprocal of the third power of the effective diameter (2). This dependence is plotted as a dark grey line and on average demonstrates better agreement with the observed distribution.

The images of the liquid water content, the vertical air flow velocity and the rainfall rate in the timeheight plane have also been produced. The averaged values of the retrieved parameters are in agreement with the Marshall-Palmer retrieval expressions.

\section{Conclusion}

The two-parameter retrieval algorithm suggested has appeared to be suitable for the real-time observations with vertically-directed Doppler radars. The algorithm provides high-resolution images of the droplet effective diameter, the droplet concentration, the liquid water content, the vertical air flow velocity and the rainfall rate. These images provide important information on the cloud and rain structure and thus improve the radar capacity for realtime observation of precipitation events.

\section{Acknowledgements}

This work has been done in the Institute of Radio Astronomy (Ukraine) in cooperation with the Meteorological Institute of Hamburg University (Germany).

\section{References}

1. H. Sauvageot. Radar Meteorology. Artech House, Boston, London, 1992.

2. R. J. Doviak and D. S. Zrnic. Doppler Radar and Weather Observations. Academic Press, 1984.

3. L. J. Battan. Radar Observations of the Atmosphere. The University of Chicago Press, Chicago, 1973.

4. D. Atlas. "Advances in Radar Meteorology", in Advances in Geophysics. New York: Academic, pp.318-478, 1964.

5. A. G. Gorelik and A. G. Smirnov. Doklady Akad. Nauk SSSR. May 1961, 139, pp. 1098-1100.

6. V. Bormotov, G. Peters, K. Schünemann, D. Vavriv, V. Vinogradov, and V. Volkov. Proceedings of 
Millennium Conference on Antenna and Propagation. Davos, Switzerland, April 2000, pp. 319-320.

7. A. Ishimaru. Wave Propagation and Scattering in Random Media. Vol. 1, 2. Academic, New York, 1978.

\section{Оценка параметров облаков и дождя по данным доплеровского радиолокатора}

\section{А. А. Безвесильный, Г. Питерс, Д. М. Ваврив}

Построение изображений параметров водяных облаков, дающих осадки, и дождя с помощью вертикально направленного доплеровского радиолокатора является важной задачей. В статье предложен алгоритм, основанный на независимой оценке эффективного диаметра и концентрации капель. Этот подход отличается от подхода Маршалла-Пальмеpa, основанного на оценке одного параметра радиолокационной отражаемости.

Показано, что подход Маршалла-Пальмера обеспечивает хорошую оценку усредненных параметров, но не годится для построения изображений параметров с высоким разрешением в координатах время - высота. Рассматриваемый подход с двумя параметрами был испытан на поляриметрическом доплеровском радиолокаторе MIRA-36. В статье приведены результаты измерений и их обработки. Предложенный алгоритм оказался приемлемым для работы в реальном времени на вертикально направленных доплеровских радиолокаторах.

\section{Оцінка параметрів хмар та дощу за даними доплерівського радіолокатора}

\section{О. О. Безвесільний, Г. Пітерс, Д. М. Ваврів}

Побудова зображень параметрів водяних хмар, що дають опади, та дощу за допомогою вертикально орієнтованого доплерівського радіолокатора є важливою задачею. В статті запропоновано алгоритм, що базується на незалежній оцінці ефективного діаметра та концентрації крапель. Цей підхід відрізняється від підходу Маршала-Пальмеpa, що базується на оцінці одного параметра - коефіцієнта радіолокаційного відбиття.

Показано, що підхід Маршала-Пальмера забезпечує добру оцінку усереднених параметрів, але не придатний для побудови зображень параметрів з високим розділенням в координатах час - висота. Розглянутий підхід 3 двома параметрами було випробувано на поляриметричному доплерівському радіолокаторі MIRA-36. В статті наведено результати вимірювань та їх обробки. Запропонований алгоритм виявився придатним для роботи у реальному часі на вертикально спрямованих доплерівських радіолокаторах. 